\title{
(2) Genetic enhancement, TED talks and the sense OPEN ACCESS of wonder
}

\author{
Loredana Filip
}

Fakultät für Sprach- und Literaturwissenschaften, Department III - Anglistik und Amerikanistik, LudwigMaximilians-Universität München, München 80333, Germany

\section{Correspondence to} Loredana Filip, LudwigMaximilians-Universitat Munchen, Munchen 80333, Germany; l.filip@Imu.de

Accepted 25 March 2021

Check for updates

(c) Author(s) (or their employer(s)) 2021. Re-use permitted under CC BY-NC. No commercial re-use. See rights and permissions. Published by BMJ.

To cite: Filip L. Med Humanit 2021:47:210-218.

\section{ABSTRACT}

TED talks are an emergent and hybrid genre (Ludewig) and have become a highly successful disseminator and populariser of scientific knowledge (Sugimoto et al). The popular appeal of TED may also stem from the promise to deliver life-changing insights in a short amount of time. Besides, TED talks may rely on a science fictional 'sense of wonder' (Sawyer) in their representations of new technologies. CRISPR-Cas9 is a genome-editing technology that has captured the imagination of scientists. Science's 2015 Breakthrough of the Year, CRISPR became the focus of ethical debates because of its potential to engineer the human. Rather than its therapeutic use, it is the potential for enhancement that gains traction in media. For these reasons, scientists have called for "a global pause in any clinical applications of the CRISPR technology in human embryos" (Doudna). TED talks actively shape the discourse on genetics at a global level. Embedded in the American culture of selfhelp and self-improvement, TED talks produce genetic stories that may favour an optimistic representation of genetic engineering. This paper aims to pursue the following questions: how do TED's formal elements affect the representation of the genome? And how do they influence contemporary constructions of identity? By focusing on two playlists-'How does DNA work?' and 'Get into your genes' - this paper investigates the emergence of at least three formal features that inform these stories. These three recurring elementsconceptual breakthroughs, a sense of awe, and prophetic statements-also animate a sense of wonder and rely on the notion of 'vision' to define the human. In the end, TED talks aim to anticipate or even shape the future. This article argues that we need to pay close attention to how they set out to shape our 'genetic future'.

\section{GENETIC STORIES AND TED TALKS}

The scientific breakthrough of the year 2015CRISPR-Cas9-promises the 'start of a new genomic era' where 'the genetic code of virtually any species can be modified, and for more than simply self-protection'. ${ }^{1}$ CRISPR has been discovered in a bacterial immune system and it is short for 'clustered regularly interspaced short palindromic repeats'. This defence mechanism against viruses uses a protein called Cas9 to cut the viral DNA and a single guide RNA to match and bind to that particular sequence. CRISPR scientists Jennifer Doudna and Emmanuelle Charpentier proposed to use this system as a genetic engineering technology, leading to a revolution in gene editing. In a TED talk, science journalist Jennifer Kahn defines it as a 'tool that allows researchers to edit genes very precisely, easily and quickly', as scientists can now 'take an entire gene out, put one in, or even edit just a single letter within a gene'. ${ }^{2}$ The fascination with this technology hinges on at least three characteristics: it is 'better, cheaper and faster' than other geneediting tools. ${ }^{3}$ Chinese scientists have experimented on human embryos using this technique ${ }^{4}$ and while scientists have called for a global pause in any clinical applications of CRISPR in human embryosan announcement made by Jennifer Doudna ${ }^{5}$ - the potential functions of CRISPR have sparked the emergence of new genetic fictions focused on genetic engineering or even enhancements.

The TED (Technology, Entertainment, Design) platform has become a highly successful disseminator and populariser of scientific knowledge, and is a dominant cultural medium in which the implications of CRISPR have been debated. ${ }^{6}$ However, this paper assumes that the genre of TED itself may also influence the way science is communicated for the education and enlightenment of their audiences. Embedded in the American culture of self-help and self-improvement, TED talks do not merely communicate facts, but they aim to tell stories. Historically, the self-help culture of America has been traced back to the constitutional right to pursue happiness as well as to Benjamin Franklin's Autobiography as an early example of self-fashioning and American individualism that define this culture. ${ }^{7}$ Self-help in America has been associated with an ideology of positive thinking and a strong belief in the 'power of mind over matter ${ }^{8}$ to cure, improve or create a better version of the self. The TED focus on the 'power of ideas' could be seen as a reflection of this belief in the power of mind. Besides, Anne Harrington has identified a 'new kind of therapeutic self-help culture in which scientific experts trained in psychology or medicine tell everyone else how to live happier, healthier, and more productive lives ${ }^{10}$ and TED seems to follow this tradition.

Self-help also became a booming industry which counts on feelings of inadequacy while trying to sell happiness. This commodification of feelings is traceable in TED as well. In their guide to presenters, organisers of TED events encourage the evocation of 'honest, contagious emotions wonder, optimism, anger, surprise'. ${ }^{11}$ This affective exchange suggests that the audience is not just a passive consumer, but a proactive interlocutor. Following Michel De Certeau, I believe there are different 'ways of using' these talks. ${ }^{12}$ However, I will focus on the inspirational dimension of these talks, because this is one important way in which they are both produced and received: as a motivational tool. 
On their website, TED also asks its audience to select their interests, so it may be able to recommend talks. Personal growth and self-improvement feature prominently in their list of choices. Furthermore, the positive outlook of TED, the confessional tone of its talks, and the focus on success stories or pursuits of selffulfilment are just a few other elements that place TED in the culture of self-help. TED talks may thus favour the emergence of optimistic stories focused on genetics and they may contribute to the genomic hype that emerged in recent decades. In other words, gene editing may emerge as a useful tool to improve the self. As such, self-help culture shapes the way gene editing is portrayed in TED. In this paper I consider several key trends that can be found in TED talks focused on genetics, trends that are also inspired by self-help. They include the sense of 'genetic wonder', and its correlated effects: the dematerialisation of DNA, the figure of the genius as a template to define the human self in visionary terms, and the imagining of a posthuman future. $^{13}$

As of 13 March 2020, TED's home page listed 72 talks on the topic of genetics. Some of these talks are grouped in four playlists: 'How does DNA work?', 'Best science and tech of 2016', 'Jawdropping science breakthroughs' and 'Get into your genes'. ${ }^{14}$ This paper will focus on two of these playlists, 'How does DNA work?' and 'Get into your genes', because these two playlists aim to tell stories of the self. 'How does DNA work?' begins its summary with the lines 'Your DNA makes you, you - but how does it work?'15 and 'Get into your genes' also encourages its audience to 'try on these talks about the traits that make you who you are'. ${ }^{16}$ Accordingly, both playlists set out to fashion the self against a genetic background. They do not merely disseminate scientific knowledge, but they also contribute to contemporary constructions of identity and processes of subject formation. This is particularly relevant when considering the genre of TED talks: their mass production, global reach and popularity suggest that its proposed models are highly influential and may potentially be borrowed by its audience. ${ }^{17}$ Furthermore, the formal features of TED may also influence how this genetic envisioning of the self occurs.

TED calls for its audience to 'find your potential', 'broaden your horizon', 'learn something new', 'shift your perspective' or 'explore what's possible'. ${ }^{18}$ This approach towards the self becomes visible on a formal level as well: speakers may tell stories of personal transformation, usually in a confessional tone-stories of conversion, personal crisis and acts of overcoming. As such, TED may promote a self-help 'ethic of total self-creation' and free will. ${ }^{19}$ In a genetic context, this approach towards the self may have peculiar consequences: the prospect of genetic enhancement raised by CRISPR-Cas9 and related technologies may emerge as another form of self-actualisation or transformation from within, rather than a problematic pursuit that needs critical attention. TED may thus favour a stance that celebrates the idea of using gene editing for human improvement.

Some of the ethical concerns raised by critics of human enhancement include matters of safety, social equality and 'human nature'. ${ }^{20}$ Rather than trying to define what human nature is, this paper aims to approach the topic of genetic enhancement differently. It explores the ways in which rhetorical devices and visual strategies employed by TED and its speakers may contribute to the way the self is defined. It assumes that the idea of self-help influences the framing of genetic stories and it aims to illustrate how this cultural milieu may affect the dissemination and reception of genetic discourse around selfhood and enhancement.

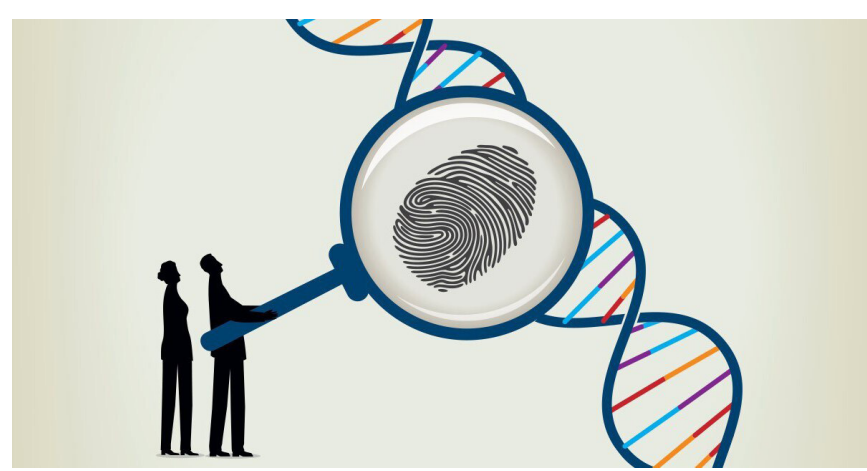

Figure 1 Image for TED's playlist on 'How does DNA work?' Credit: TED. Attribution 4.0 International (CC BY 4.0). https://www.ted.com/ playlists/357/how_does_dna_work/.

\section{HOW DOES DNA WORK?}

The playlist 'How does DNA work?' is framed by an image of DNA (see figure 1). Two figures-a man and a woman—engage in an act of looking. They are looking forward and upward at the same time, which recalls the notion of future progress. The act of looking upward also invokes a sense of transcendence, the existence of something bigger than the human selves, which is the DNA. Furthermore, this act is also enhanced by an optical tool: a magnifying glass. The man holds it to see the DNA more closely, while the woman stands by his side. This choice may not be coincidental, since the CEO of GenomeQuest Richard Resnick has also emphasised the fact that the decision to sequence the human genome has been taken by men. ${ }^{21}$ Data scientist and entrepreneur Riccardo Sabatini introduces as his main character in his genetic story Dr Craig Venter, the 'first man' who sequenced the genome. ${ }^{22}$ Even more, both playlists are dominated by male speakers, as there is only one female speaker present in each: Jennifer Doudna among six male speakers in 'How does DNA work?' and Jennifer Kahn among five male speakers in 'Get into your genes'. But there may be another reason why the male figure holds the magnifying glass: he may stand for the figure of the genius, a quality that has been repeatedly associated with male scientists.

Thus, the trope of the magnifying glass suggests that the man is engaged in an act of exploration and discovery, which is not only an act of looking, but also a visualising act. Accordingly, it emphasises the visionary power of the genius to envision new knowledge and to make prophecies. However, the act of exploration is imbued with another layer of meaning, since the glass functions like a mirror. The man sees the image of a fingertip in the vast genetic pattern of the DNA. If fingertips are unique signs of individuality, then the DNA holds the key to accessing one's own true identity. So, the act of exploration becomes an act of introspection too-an act of looking inward. This act of looking inward recalls the 'inward turn' of self-help culture which signals a 'move toward a greater sense of interiority and a focus on the self. ${ }^{23}$ Even more, the analogy between these two patterns may also suggest that the 'core' of the human self is transcendent, just like the DNA. Human imagination may be deemed as the supreme and definitive quality of the human because it allows the genius to see-in all of its connotations: not only visual perception, but also inner vision and prophetic vision. Finally, by focusing on the notion of pattern, design or order, this image downplays the materiality of both the DNA and the human self. It is the pattern of the double helix which is mostly visible, just as the unique pattern carved in the human body is definitive for an individual. 
Accordingly, this image is governed by what Andy Sawyer describes as a science fictional 'sense of wonder', which illustrates the convergence of these three forms of vision: looking-forward, or the prophetic dimension, since wonder appears by 'creating realistically plausible future' scenarios; looking-upward, or a sense of transcendence, especially since wonder has been associated with a sense of awe or the sublime; and looking-inward, considering that the sense of wonder is also akin to conceptual breakthroughs. ${ }^{24}$ Even more, the conventions of the TED genre itself advance and support the emergence of these three elements. TED talks aim to deliver "life-changing insights ${ }^{25}$ and, as their slogan confirms, they rely on the notion of 'ideas worth spreading'. So, they also celebrate conceptual breakthroughs as they introduce new scientific inventions and innovations. TED talks also have a futuristic dimension, since they try to anticipate or predict future trends and discoveries. Finally, these ideas and insights also aim to thrill and inspire the audience, so they may also rely on fostering a sense of awe. ${ }^{26}$ Accordingly, then, TED talks share these significant features with the genre of science fiction. ${ }^{27}$

Wonder connotes amazement, awe or marvel, but also the cognitive act of speculating, thinking or questioning. It is irreducible to the Romantic sublime or an act of curiosity, but it contains them both. ${ }^{28}$ It is an element that may be associated with the figure of the genius or an eureka moment because it couples scientific inquiry with a spiritual dimension. Hence, wonder allows the paradoxical coexistence of both a sense of plausibility and a feeling of mysticism. Besides, self-help authors may also rely on the sense of wonder to strengthen their claims of mind-power. ${ }^{29}$ Whether it accompanies the visions of the genius or the creative visualisations of the selfhelp practitioner, wonder can be used to claim the superiority of the mind.

The self-help 'ethic of total self-creation' may affect the dissemination and reception of the genetic stories of TED talks. Bowdon believes that the 'essence of self-help' is to 'consciously decide what we will think, not allowing genes or environment or fate to determine our path'. ${ }^{30}$ As such, the act of self-creation involves a struggle to break free of genetic predispositions. ${ }^{31}$ However, the genius may also decide to use the genetic 'toolbox' to explore the limitless potential of the human. In this scenario, genes are not imprisoning the self, but they actually inspire the act of self-creation. The trope of vision and visionary thinking mediates the emergence of this narrative of self-mastery and self-actualisation via genetic manipulation-that is, genetic enhancement.

The TED talks featured in 'How does DNA work?' rely on some of the elements that the image of DNA exposes, especially the focus on vision and visionary thinking. For instance, biomedical animator Drew Berry summons two geniuses, Galileo Galilei and Charles Darwin, to celebrate their cognitive and transformative power to visualise the moon or the tree of life. ${ }^{32}$ His animations also aim to illustrate visually how molecules interact. James Watson recounts his endeavour to build the visual model of DNA. ${ }^{33}$ Jennifer Doudna makes a visual analogy between genetic engineering and word editing, while Spencer Wells understands human DNA as a blueprint that can explain human diversity. ${ }^{34}$ Biotech entrepreneur Barry Schuler endorses the image of the human self as a creator: he calls for a usage of the 'genetic toolbox' not only for reading purposes, but also writing. ${ }^{35}$ Here he talks about modifying organisms, such as yeast or the Pinot Noir organism. In various ways, all of these speakers rely on the trope of vision to explain how we can approach and understand DNA.
To focus critically on this trope is not to ignore the significance of the speakers' arguments. For instance, Doudna emphasises the ethical issues that need to be considered since the prospect of genetic engineering has gained in prominence. And of course, visualisations do help us understand 'unseeable biology', as Berry illustrates. However, in order to make their talks more accessible—a key requirement of the TED model—some of these speakers tend to overemphasise the visual element. This preference for the trope of vision could also be understood in connection to the self-help promotion of visualisation. However, when the DNA is defined as a visual model, design or pattern, this analogy also contributes to an underestimation of DNA's materiality. I investigate the implications of this approach in Riccardo Sabatini's 'How to read the genome and build a human being' (2016), which is the first talk featured in the playlist.

\section{Riccardo Sabatini: 'How to read the genome and build a human being'}

Riccardo Sabatini begins his TED talk with a personal confession and a shocking discovery: the realisation that his mother is a $3 \mathrm{D}$ printer. He compares pregnancy or the act of building a human with 3D printing and he goes on to describe his fascination with the vastness of data that this process entails. ${ }^{36} \mathrm{He}$ also introduces his work at the company Human Longevity, which was founded by Peter Diamandis and Craig Venter. ${ }^{37}$ Here they collect genomes and use machines to assist them in the act of 'translation': by reading genomes, they try to predict human traits such as height, eye colour, gender, age or even an entire human face. He claims that the reason behind this work is the promise of personalised medicine. However, Sabatini also ends on a utopian note: by imagining the possibility of choosing the future of our species.

'How to read the genome and build a human being' uses selfhelp rhetoric right in its title, since it borrows the style of an instruction manual-the 'how-to' logic. The title also highlights two particular acts that are complementary: the cognitive act (of reading and understanding) and the creative act (of building), both of which are practised by the genius. They also recall Schuler's call to use the genetic toolbox to both read and write the genome. But the trope of 'building a human being' also recalls another literary tradition: the early, proto-versions of science fiction, that is the figure of Frankenstein, the scientist who is 'playing God'. However, Sabatini reframes the story and infuses it with a positive dimension. The act of 'playing God' is translated into a communal effort: it is 'the future we're building as a humanity' that takes centre stage, rather than the isolated act of creation. ${ }^{38}$ Schuler also responds to this tradition by asking the audience: 'If we engineer organisms, are we playing God? ${ }^{39}$ He then emphasises the practice of 'reorganising things', rather than 'inventing molecules', which he deems a 'natural' thing to do. ${ }^{40} \mathrm{Or}$, as he puts it, working with Nature, rather than against it, is 'the next step in humankind's evolution'. ${ }^{41}$

So, both speakers rethink the idea of genius in communal terms, as an endeavour of the community (which includes the audience or the addressee), rather than as an individual act. The first-person plural used by both speakers implies that 'we' are not ordinary bystanders, but 'we' are also promised access to visions. It makes us feel like we want to take part in the act of creation, an effect that is achieved via the evocation of a 'sense of wonder' too. This idea is backed up by some of the responses in the comments section of Sabatini's talk, which include remarks such as 'marvellous', 'it is amazing' or 'it's awesome'. So, 'we' are motivated to change. But how does this sense of wonder emerge? 
Metaphors from information science are often used to explain DNA, a practice that has been criticised by commentators such as Lily Kay. ${ }^{42}$ However, many TED speakers deploy these tropes. Sabatini's talk tries to capture the 'essence' of life that is to be found in a vial of blood: the human genome. ${ }^{43}$ Similarly, Watson begins his talk by asking, 'What was the essence of life?' and citing Schrödinger's answer: the information in our chromosomes. ${ }^{44}$ Watson thus explains how DNA may be a 'digital-type information' composed of a 'four letter code'. 45 Schuler defines the genome as an 'instruction manual', 'the programme', 'the code of life' while molecules are described as letters: A, T, C, G. ${ }^{46}$ Analogies with computers, programmes, editing software or Microsoft Office appear often. Juan Enriquez talks about the 'lifecode' that allows us to programme life. ${ }^{47}$ Wells understands DNA as a 'historical document'. ${ }^{48}$ This focus on information tends to downplay the role of materiality or to frame information as the superior 'element'. As such, these speakers offer only partial explanations of DNA and they incite ideas of an easy manipulation of the body, carving the path to visions of human enhancement.

In his talk, Sabatini does not merely follow the trend to associate DNA with code. He also introduces the audience to 'the visual perception of what is the code of life' ${ }^{49}$ Even more, he claims to bring Dr Craig Venter on stage, not the man in the 'flesh', but the man as an amount of information contained within a parade of oversized books on stage. These books contain Venter's genetic code and their size and large number, as they occupy the whole stage, aim to capture the magnitude of the genome. This gesture does not only imply that human identity and DNA can be equivalent. It also evokes a sense of awe at the vastness of data; Sabatini wants to show 'how big and enormous' this code is. ${ }^{50}$ Millions of letters make up these 'five hundred pages (that) is the miracle of life that you are'. 51 In other words, by bringing in the 'miraculous' aspect of DNA, Sabatini infuses it with a transcendent dimension. ${ }^{52}$ Even more, he makes an analogy between these books and the Bible. Reading from 'Chromosome 14, Book 132', Sabatini uses irony to mimic the Bible, inciting a reaction of laughter from the audience. ${ }^{53}$ $\mathrm{He}$ also aims to instil the belief that the genome may be the new sacred book of life, especially since he claims that this is a 'wonderful book, a mighty book'.54

The practice of using textual metaphors to explain genetics has been intensively criticised by many commentators, including Evelyn Fox Keller and Judith Roof. ${ }^{55}$ Dorothy Nelkin has also done a critical review of four groups of contemporary genetic metaphors: genes as essences of personal identity, genes as sacred entities, genes as determinants of destiny and genes as commodity. According to her, by referring to the genome as the Bible, geneticists may promote a vision of a mystical DNA as a way to 'explain the essence of human existence, to imagine immortality and to anticipate human fate'. ${ }^{56}$ As such, through metaphors, 'genetics can seem to be a source of salvation or a means of exploitation and control'. 57

Sabatini does not only rely on metaphorical thinking to explain how the genome works, but he also celebrates such imaginative endeavours. Sabatini believes that humans may be able to manipulate this transcendent force, hence the importance of imagination. Only the visionary power of the genius can allow the human to manipulate this sacred book. He also stages his belief that the genome could be grasped conceptually by picking up books, reading from them and showing what they mean. The implication is that we can control this code of lifewe can read, edit, predict and play with it. In the end, Sabatini does not only reduce life to code, but this analogy also allows

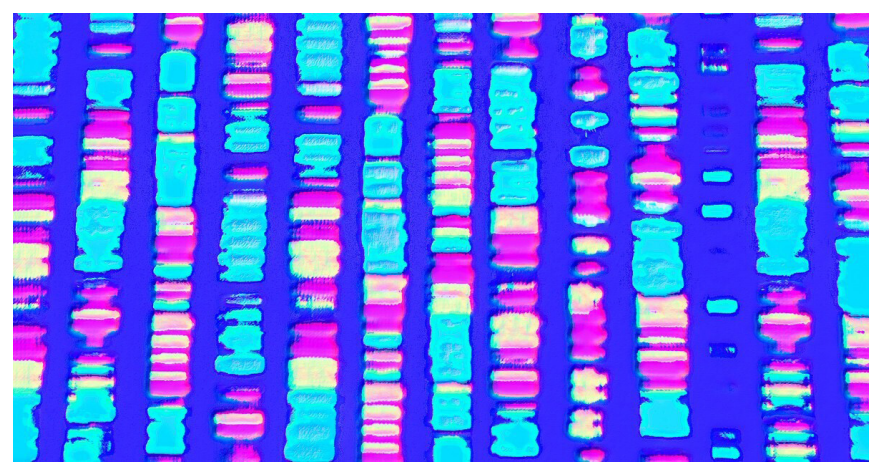

Figure 2 Image for TED's playlist on 'Get into your genes' Credit: TED. Attribution 4.0 International (CC BY 4.0). https://www.ted.com/ playlists/494/get_into_your_genes/.

him to define it as metaphysical. This may seem at odds with the attempt at quantification. Yet, when the focus lies on the human power of imagination and innovation, one has the tools to deal with the metaphysical too. Even more, this metaphysical dimension helps the speaker back up the claim for the creation of an ideal, utopian future where we are able decide if we live or die: 'we will be confronted with decisions that we never had to face before about life, about death, about parenting, ${ }^{58}$ It is not only the desire for personalised medicine or better health that drives this narrative: it is also the belief in some utopian future where we can choose the future of our species. Even though it is not named explicitly, this rhetoric endorses the prospect of human enhancement. Since we could presumably make choices about life and death, Sabatini opens the door to think about indefinite life extension, especially since the work of the company focuses on longevity. This utopian dimension becomes even more apparent in the talks of Juan Enriquez, who is featured at the end of both playlists.

\section{GET INTO YOUR GENES}

The image that frames the 'Get into your genes' playlist highlights the appearance of molecules as the building blocks of life (see figure 2). Since these blocks are arranged in a certain pattern, as they are grouped together following certain rules and qualities (like colour), the attention is drawn to some hidden design. Once again, the main function of the genes is to ensure the maintenance of a certain order. The pattern also resembles the flow of some binary code or language, since there are two colours in particular which keep recurring: the bright blue and the bright pink. Even more, the fluorescence of the blocks may invoke a sense of magic or wonder. Rather than emphasising their materiality, this glowing brightness seems to hint at some transcendent dimension or visionary aspect. In short, this image invokes similar elements that have been identified in the previous playlist too.

The TED talks in this playlist also pick up on some of these features and on the self-help tradition and rhetoric. Geneticist and indigenous rights activist Keolu Fox aims to empower indigenous communities by including them in genetic research. His 'vision' is 'to make genetic research more native'. ${ }^{59}$ However, his belief that 'what makes us unique as Hawaiians' is 'our genetic makeup' engages in the practice of reducing identity to genetics. ${ }^{60}$ By introducing the role of the 'citizen scientist', ${ }^{61}$ Fox does not only democratise scientific practice, but he also envisions it as a form of self-help for marginalised communities: of taking an active stand by participating in research. However, his proposition is also controversial: he suggests that Hawaiians 
should use mobile genome sequencers, pocket-size devices that can sequence their genome on the go, without needing a laboratory. It remains unclear how this practice will lead to an empowerment of the Hawaiians, rather than supporting a form of genomic surveillance or social control that can invade their privacy. The role of the citizen scientist envisioned by Fox seems to have more in common with DIY practices, rather than the collaborative effort of a community. ${ }^{62}$

Open-science advocate Stephen Friend also believes that we should become our own experts in identifying and treating diseases. His research project studies individuals who do not get sick in order to understand how we could develop preventive therapies. To assist such projects, he encourages us to share our DNA, which he phrases as a willingness to look inside ourselves ${ }^{63}$ rather than acting as voyeurs. In another talk, entrepreneur Richard Resnick presents the idea of using the genome as a universal diagnostic. His call to 'wake up and tune in' also encourages us to share our DNA in order to actively work for 'the betterment of mankind'. ${ }^{64}$ This includes living longer lives, but also the judgement of characters: finding out how qualified a presidential candidate is, how compatible our partners are with us or whether they are willing to cheat.

These calls to look inside ourselves recall the 'inward turn' of self-help. They reinforce a view of genes as the essence of personal identity and they bypass concerns about privacy. As such, the act of sharing our genetic data is introduced as a practice that mediates self-understanding. These speakers return to the notion that the individual has to be more proactive, especially when it comes to choosing the future of humanity. In various ways, they introduce longevity as a primary goal of their imagined future. What remains problematic is not longevity as such, but the ableist underpinnings. Self-help may endorse the belief that through mind-power, physical limitations can be conquered. ${ }^{65}$ The body is deemed as a vulnerable agent that has to be mastered or replaced. This idea lies at the core of human enhancement too, which makes an explicit appearance in Bowdon's text, where the possibility "to keep alive the "software" of our brain long after our body has given up, then perhaps have it transplanted into a new corpus' is entertained. ${ }^{66}$ So if human enhancement is all about 'mitigating disease' and 'preserving life', ${ }^{67}$ then these speakers come close to that idea. The focus on immortality becomes even more apparent in the talks of Juan Enriquez, whose visibility and presence at TED has increased throughout the years.

Enriquez is a futurist who 'thinks and writes about the profound changes that genomics and brain research will bring about in business, technology, politics and society. ${ }^{68} \mathrm{He}$ published a book entitled Evolving Ourselves: Redesigning the Future of Humanity-One Gene at a Time together with Steve Gullans and he is the only speaker who is featured in both playlists. He is a very beloved and prolific TED presenter as he has given nine talks so far. Six of these are concerned with the future of humanity as a species, as their titles attest: 'The next species of human', 'Will our kids be a different species?' and 'What will humans look like in 100 years?'. This last talk features at the end of the 'Get into your genes' playlist, as if it aims to offer a summary or conclusion to the genetic story. Enriquez gets the final word in 'How does DNA work?' as well, where he is featured with his talk on 'We can reprogram life. How to do it wisely'. Like Sabatini, Enriquez uses the 'how-to' self-help paradigm in his title too.

\section{Juan Enriquez: 'What will humans look like in 100 years?'}

'What will humans look like in 100 years?' begins with the question: 'Is it ethical to evolve the human body??. ${ }^{69}$ Enriquez traces

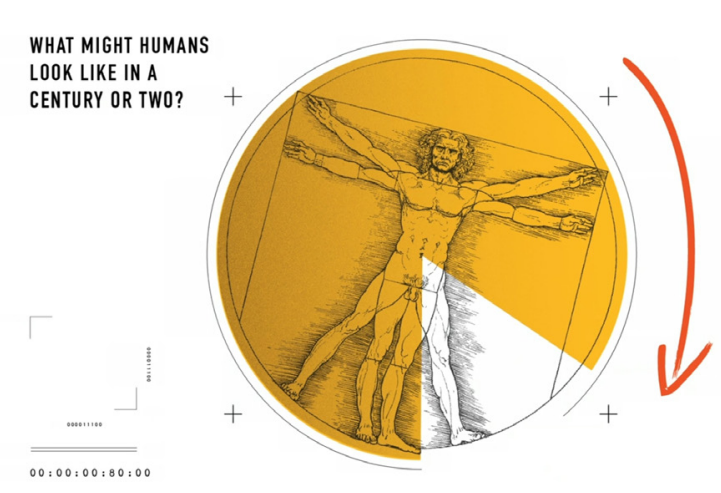

Figure 3 Image of the Vitruvian Man used by Juan Enriquez in his talk: 'What will humans look like in 100 years?' Credit: TED. Attribution 4.0 International (CC BY 4.0). https://www.ted.com/talks/juan_ enriquez_what_will_humans_look_like_in_100_years/.

a progressive genealogy of prosthetics, from the iron hand to the present-day prosthetics made by Hugh Herr to the prosthetics that are 'coming inside the body', such as artificial knees or hips. ${ }^{70}$ He emphasises the relevance of those prosthetics that can develop a 'symbiotic relationship with the human body', such as a heart peacemaker, which becomes essential for survival. ${ }^{71} \mathrm{He}$ then celebrates the work done by the Centre for Extreme Bionics as he envisions the future possibilities for humanity. For instance, if the diameter of a particular nerve were increased, the human could even potentially 'step out of the way of a bullet', ${ }^{72}$ an image recalling the iconic scenario from the science fictional Matrix movies. Enriquez goes on to talk about Phonak hearing aids, which cross the threshold 'from where prosthetics are something for somebody who is "disabled" [... to] become something that somebody who is "normal" might want to actually have', since they may facilitate what Enriquez calls 'superhearing. ${ }^{73}$ Enriquez does not reflect on privacy issues or the ableist aspect of his comments, but goes on to argue that genetic enhancement may be even more desirable than such prosthetics: 'And maybe the ultimate prosthetic isn't having something external, titanium. Maybe the ultimate prosthetic is take your own gene code, remake your own body parts, because that's a whole lot more effective than any kind of prosthetic'. ${ }^{74}$

This view assumes that the body is both measurable and improvable. Enriquez uses the image of the Vitruvian man to support his vision (see figure 3). The image of the body framed by squares and circles, whose proportions can be calculated, furthers the speaker's belief in an evolving, harmonious and perfectible body. Even more, the slight tilt in the image, the plus signs in the corners and the focus on one of the legs as one piece or fragment of the entire body suggest a photographic capture of it. In opposition to drawings, digital images allow even more control over their features, such as zooming in and out or the various focalisations. This visual aspect therefore strengthens the trope of vision as the supreme quality of the genius. Leonardo Da Vinci has become a stereotypical figure for the genius who uses his visionary power: the power of the human to continuously shape the future and to innovate. By means of his Vitruvian Man analogy, Enriquez also celebrates human imagination as the source of great discoveries and achievements, as the superior quality of the human. He updates this iconic image of Renaissance humanism to suggest a posthuman future through genetic enhancement. 
In one of his most recent talks on 'The age of genetic wonder', Enriquez reinforces his belief in an editable body by relying on the software-hardware analogy from information sciences:

programmable life forms are also going to change the world because once you can programme cells in the same way as you programme your computer chip, then you can make almost anything. So your computer chip can produce photographs, can produce music, can produce film, can produce love letters, can produce spreadsheets. It's just ones and zeroes flying through there. If you can flow ATCGs through cells, then this software makes its own hardware, which means it scales very quickly. ${ }^{75}$

Enriquez's notion of programmable life relies on an analogy between genetic code and binary code. It supports a dualist conception of cells and genes, which reflects the Cartesian dualist understanding of body and mind. Genes act like the 'mind' that is in charge of the body. Accordingly, there is an implicit belief in the superiority of the mind over the body, which is reminiscent of the self-help faith in human vision or thoughts that can change the body. Micki McGee has also argued that the metaphor of 'the self as a computer with mind as software directing body as hardware' also operates in self-help literature. ${ }^{76}$ For instance, he traces this feature in the work of Tony Robbins, one of the most influential self-help writers, and writes that 'Imagining that the brain is hardware for which thoughts and feelings are little more than software is an ideology with its roots in the seventeenthcentury mechanism of thinkers such as Rene Descartes'. ${ }^{77}$ However, in the case of Enriquez, the mind is replaced by 'genes' as the new 'mind' that governs the body.

Furthermore, Enriquez imagines something even greater: not only the possibility to heal, but also to enhance the human. In other words, the discourse of self-help may have assisted the emergence of genetic narratives focused on the prospect of human enhancement. Human enhancement is the proposed conclusion offered by these two playlists. Ideas of enhancement are offered that call for the body to be manipulated, that reduce life to a set of instructions and that hold the promise of future immortality. Enriquez makes such a proposition at the end of his talk. 'What will humans look like in 100 years' ends with an imagined future of radically redesigned bodies, where consciousness reigns supreme over the vastness of the universe:

Or could you transplant that consciousness into something that would be different, that would last in space, that would last tens of thousands of years, that would be a completely redesigned body that could hold consciousness for a long, long period of time?

And let's come back to the first question: Why would you ever want to do that? Well, I'll tell you why. Because this is the ultimate selfie. (Laughter)

This is taken from six billion miles away, and that's Earth. And that's all of us. And if that little thing goes, all of humanity goes. And the reason you want to alter the human body is because you eventually want a picture that says, that's us, and that's us, because that's the way humanity survives long-term extinction. And that's the reason why it turns out it can be unethical not to evolve the human body even though it can be scary, even though it can be challenging, but it's what's going to allow us to explore, live and get to places we can't even dream of today, but which our great-great-great-great- grandchildren might someday. ${ }^{78}$

Thus, Enriquez finishes his talk with the prospect of human enhancement which he justifies as the only solution to the extinction of the species. Human enhancement becomes mandatory, which recalls the self-help pressure to improve the self: betterment is not only a choice, but an obligation.
The desire to explore the entire universe chimes with an imperialist zeal to conquer new spaces. But it also diverts attention from more compelling environmental or ecological issues, especially since it already assumes the destruction of the planet. The act of zooming out into the universe also bypasses ethical considerations, which become minuscule and distant. It ignores the ways in which individuals, patients or populations may be affected by such enhancement work in a more tangible way. His vision is also human-centric, since it is the survival of the human species which takes precedence here on Earth. At the same time, his selfie reference places humanity at the centre of the universe. As such, his talks reveal the intricate ways in which different discourses and ideologies support and inform one another: humanism, colonialism and ableism, to name just a few.

In the end, Enriquez is looking forward to a future of exploration, upward to the vastness of the skies and inward to human consciousness. The sense of wonder which is fostered via a sense of anticipation, scale, awe and insight is used to support the speaker's vision. The Romantic sense of the sublime is updated here to suggest a feeling of mastery and control, rather than reverence towards something greater than the human self. At first, it may seem paradoxical that the human species can survive only by changing itself in a radical way. But since Enriquez already understands the human as a genius, or sees the genius as the essence of the human, he would regard this change as a form of self-actualisation, rather than total redesign. Once again, the figure of the genius emerges as the epitome of self-mastery or self-control. Enriquez proposes a humanist vision for a postgenomic world, which is problematic because of the essentialist claims that also sustain the prospect of genetic enhancement.

\section{CONCLUSION}

In conclusion, the formal choices that have been taken in the production of TED talks on the topic of genetics hold great consequences for how these stories might be interpreted, propagated and popularised. For instance, seemingly harmless rhetorical choices- the reduction of DNA to code, the reliance on visual metaphors to understand the genome, the analogy between life and DNA, and the consequent association of DNA with some metaphysical force-may all contribute to the rise of human enhancement ideals. Furthermore, some of these choices gain a new meaning once we consider the cultural milieu in which they emerge: the American tradition of self-help as one of the most influential backgrounds for TED talks.

The calls to be more proactive, to take responsibility and to democratise scientific research have some grounding in self-help discourse, but they are also relevant and beneficial to how we might approach our 'genetic future'. Self-help is a hybrid and complex genre and we should avoid diminishing its own applicability. However, the reliance on some of its most popular thoughts and trends, especially the humanist tradition, may influence the communication of genetic narratives in a prejudiced way. The pervasion of self-help ideas such as mind-power (and the spiritual dimension attached to it) or self-creation (for endless betterment) shape the way gene editing is portrayed: as a progressive endeavour of the genius to improve the human. These ideas also lead to the conviction that freedom and selfactualisation can be achieved only by controlling the body. The conflation of self-help rhetoric and genetic discourse may thus lead to a belief in human essentialism which culminates with a belief in human enhancement. 
In order to define the human, the genius appears as an important figure whose visionary power promises future progress, self-transcendence and insights. These ideas are supported on a formal level as well, since speakers such as Juan Enriquez and Riccardo Sabatini rely on the evocation of a sense of wonder to highlight and mirror acts of looking forward, looking upward and looking inward. As this analysis of TED talks has shown, genetic enhancement mobilises a belief in genes as the essence of personal identity, which on a formal level is presented as an act of looking inward. It relies on a belief in genes as sacred entities, which appears on a formal level as an act of looking upward. And it depends on a belief in genes as fabricators of the future, not only predictors. This is suggested on a formal level by the act of looking forward.

The sense of wonder also relies on metaphors that offer only partial explanations of DNA (as code), which inspire visions of genetic enhancement. But this formal choice eclipses the emergence of ethical issues, such as the eugenic underpinnings entailed by essentialist claims, the ableist connotations or the privacy issues that arise in the calls to reimagine the future. The culture of self-help frames this endeavour as a practice of selfunderstanding and probing investigation of human nature. By holding on to a notion of human nature, both proponents and critics of enhancement have overlooked the ways in which the very attempt to define the human can be problematic.

The focus on humanity monopolises the discussion and obscures the complex ways in which genetic narratives might be otherwise imagined. Even the critical voices of Jennifer Doudna or Paul Knoepfler, who are more concerned with the ethical issues of genetic engineering, still rely on the metaphor of DNA as code. Similarly, Keolu Fox speaks for indigenous communities and the importance of including them in genetic research, but he also sees genetics as the birthplace of identity. Such gestures may reflect a desire to make the content as accessible and as forceful as possible. TED talks themselves aim to reach a global population, so they should be as consumable as possible: short, powerful and clear. However, these two rhetorical choices (the dematerialisation of DNA and its association with a toolbox), which are also visible in the image used to frame the playlist 'How does DNA work?', may facilitate the emergence of narratives of human enhancement.

This is how the genetic stories of these playlists end and begin. When new technologies such as CRISPR are being developed, we need to pay attention to how scientists, geneticists or entrepreneurs introduce it to the public: to highlight the rhetorical choices that they make and to take into account the cultural landscape in which they move. TED remains a highly influential platform that introduces scientific discoveries to the public. Precisely because of this, we need to consider the genre conventions that it prefers as well as the American culture of self-help in which it is embedded, both of them affecting the dissemination and reception of science-such as, for instance, the science of genes.

\section{Twitter Loredana Filip @lore_filip}

Acknowledgements The author thanks her supervisor Prof Dr Antje Kley for the continuous support towards the paper and the research behind it. The author also thanks PD Dr Karin Hoepker and the other members of the colloquium (University of Erlangen-Nuremberg) for their valuable feedback. The author specially thanks Dr Clare Barker for her careful editing and constructive criticism that have improved the essay in meaningful ways. The author thanks all the participants of the symposium Global Genetic Fictions (Leeds University, 25-26 April 2019) for the inspiring conversations. The author also thanks the anonymous peer reviewers for their helpful comments. The author thanks Kira Hentschel for assistance during the last stages of the proofreading.

\section{Contributors $L F$ is the sole author.}

Funding The author has not declared a specific grant for this research from any funding agency in the public, commercial or not-for-profit sectors.

Competing interests None declared.

Patient and public involvement Patients and/or the public were not involved in the design, or conduct, or reporting, or dissemination plans of this research.

Patient consent for publication Not required.

Provenance and peer review Not commissioned; externally peer reviewed.

Data availability statement Data are available in a public, open access repository. The data that support the findings of this study are openly available.

Open access This is an open access article distributed in accordance with the Creative Commons Attribution Non Commercial (CC BY-NC 4.0) license, which permits others to distribute, remix, adapt, build upon this work non-commercially, and license their derivative works on different terms, provided the original work is properly cited, appropriate credit is given, any changes made indicated, and the use is non-commercial. See: http://creativecommons.org/licenses/by-nc/4.0/.

\section{ORCID iD}

Loredana Filip http://orcid.org/0000-0002-8538-9881

\section{NOTES}

1. Tianna Hicklin (2014), "The Start of a New Genomic Era." CRISPR-Cas: Engineering a Revolution in Gene Editing, Science, September 26, 2014, 2, https://www.sciencemag. org/sites/default/files/custom-publishing/documents/CRISPR-Cas9_booklet_LowRes. pdf.

2. Jennifer Kahn (2016), "Gene Editing Can Now Change an Entire Species - Forever." Filmed February 2016 in Vancouver, Canada. TED video, 03:36-04:06, https://www. ted.com/talks/jennifer_kahn_gene_editing_can_now_change_an_entire_species_ forever.

3. Paul Knoepfler (2015), "The Ethical Dilemma of Designer Babies." Filmed October 2015 in Vienna, Austria. TEDx video, 06:27-06:30, https://www.ted.com/talks/paul_ knoepfler_the_ethical_dilemma_of_designer_babies.

4. Puping Liang et al. (2015). "CRISPR/Cas9-Mediated Gene Editing in Human Tripronuclear Zygotes." Protein Cell 6, 363-72. https://doi.org/10.1007/s13238-0150153-5.

5. Jennifer Doudna (2015), "How CRISPR Lets Us Edit our DNA." Filmed September 2015 in London, UK. TED video, 11:21-11:30, https://www.ted.com/talks/jennifer_doudna_ how_crispr_lets_us_edit_our_dna.

6. For instance, TED talks have claimed over a billion online views. See Cassidy $R$ Sugimoto et al., 2013. "Scientists Popularizing Science: Characteristics and Impact of TED Talk Presenters." Plos One 8, no. 4: e62403. https://doi.org/10.1371/journal. pone.0062403. CRISPR is also now listed as a TED topic: there are at least 10 talks dedicated to the subject.

7. See Tony Anderson (2018), "Benjamin Franklin: The Unlikely Father of Self-Help." Society and Culture, January 17, 2018, https://www.blinkist.com/magazine/posts/ benjamin-franklin-father-self-help.

8. While discussing self-help author Tony Robbins, Micki McGee defines "the power of mind over matter" as "classic American self-improvement." See Micki McGee (2005), Self-Help, Inc.: Makeover Culture in American Life (Oxford: Oxford UP), 60.

9. Under "Our Organization," the spreading of ideas features as the main mission of TED: "We believe passionately in the power of ideas to change attitudes, lives and, ultimately, the world." https://www.ted.com/about/our-organization.

10. Anne Harrington (2008), The Cure Within: A History of Mind-Body Medicine (NY, London: W.W. Norton \& Company), 249.

11. https://www.ted.com/participate/organize-a-local-tedx-event/tedx-organizer-guide/ speakers-program/prepare-your-speaker/rehearsals.

12. I do not wish to suggest that consumers of TED talks blindly adopt the ideas of the speakers. And I do not wish to deny the myriad ways in which the audience makes sense of and uses these talks, maybe even in subverting ways. But assuming an audience that wants to feel inspired, I will focus on the repercussions of such an exchange. See Michel De Certeau (1984), The Practice of Everyday Life (Berkeley, Los Angeles, London: University of California Press), xiii.

13. Juan Enriquez, 2018, "The Age of Genetic Wonder." Filmed November 2018 in Geneva, Switzerland. TEDx video, 18:06. https://www.ted.com/talks/juan_enriquez_the_age of_genetic_wonder_feb_2019.

14. https://www.ted.com/topics/genetics.

15. https://www.ted.com/playlists/357/how_does_dna_work.

16. https://www.ted.com/playlists/494/get_into_your_genes.

17. According to Sugimoto and her colleagues, data from Alexa.com suggests that "the TED audience is young and well-educated, with the age-range 18-24 and the 
education status 'Graduate School' being overrepresented amongst ted.com visitors compared to the rest of the Web." However, further research of the audience needs to be done, including the audience of these talks on genetics. See Cassidy R Sugimoto et al. (2013) "Scientists Popularizing Science: Characteristics and Impact of TED Talk Presenters." Plos One 8, no. 4: e62403. https://doi.org/10.1371/journal.pone.0062403.

18. These calls appear while browsing through videos and playlists as part of the "TED recommends" advertisement.

19. Tom Butler-Bowdon (2003), 50 Self-Help Classics (London, Yarmouth, Maine: Nicholas Brealey Publishing), 196.

20. Harvard philosophy expert Michael J Sandel (2007) is concerned about our safety and fairness, but also about the idea of tempering with our human nature. See Michael Sandel, The Case Against Perfection: Ethics in the Age of Genetic Engineering (Cambridge: Harvard UP). Similarly, Francis Fukuyama deems the prospect of human enhancement as immoral and tries to reinforce a view of "human dignity." See Francis Fukuyama (2002), Our Posthuman Future: Consequences of the Biotechnological Revolution (New York: Farrar, Straus, and Giroux).

21. Richard Resnick (2011), "Welcome to the Genomic Revolution." Filmed July 2011 in Boston, USA. TEDx video, 01:08, https://www.ted.com/talks/richard_resnick_welcome_ to_t he_genomic_revolution. This is how he comments on the decision to sequence the human genome: "a group of people - all, by the way with $Y$ chromosomes decided to sequence it."

22. This focus on $\mathrm{Dr}$ Craig Venter alone reinforces a view of scientific discovery as the work of a genius. It also obscures the competitive and collaborative effort of both Venter, who privately funded Celera Genomics to sequence the genome, and the team of the Human Genome Project, which relied on public funding.

23. See McGee, 76-77.

24. Andy Sawyer (2014), "Science Fiction: The Sense of Wonder," in The Bloomsbury Introduction to Popular Fiction, ed. Christine Berberich (London: Bloomsbury Publishing), 87-107 (p. 97).

25. Julia Ludewig (2017), "TED Talks as an Emergent Genre," CLCWeb: Comparative Literature and Culture 19, no. 1, 5.

26. This futuristic dimension is visible not only in the content of individual talks, but it is also stated on the TED website. Under "TED Science Standards" and "TED Content Guidelines," the role of speculation features prominently: "At TED, we're interested in understanding the potential implications of new scientific findings. This is essential in motivating further exploration and discovery. So we are comfortable inviting scientists to speculate on the potential implications and applications of their work." https:// www.ted.com/about/our-organization/our-policies-terms/ted-science-standards. Under "How TED works," the spreading of great ideas is meant to "feed the desire to help create a better future": https://www.ted.com/about/our-organization/how-tedworks. And under the "History of TED," we read that "TED conferences and events continue to inspire, motivate and thrill attendees": https://www.ted.com/about/ our-organization/history-of-ted. Accordingly, attendees have also described the TED experience as a "journey into the future": https://www.ted.com/about/conferences.

27. Julia Ludewig has approached the genre of TED as an "emergent genre" that shares features with the memoir, the academic lecture and the sales pitch. However, the genre of science fiction may be another genre TED borrows from.

28. Edmund Burke's Philosophical Enquiry into the Origin of our Ideas of the Sublime and the Beautiful and Immanuel Kant's aesthetic philosophy are the two most commonly relied-upon sources to delve into the Romantic sublime. For a discussion of how the sublime is used in science fiction, see: Cornel Robu (1988), "A Key to Science Fiction: the Sublime," Foundation 42 (Spring), 21-36. Farah Mendlesohn (2003) claims that the "sense of wonder is the emotional heart of sf. David Nye has described this reaction as the appreciation of the sublime" (3). See: Farah Mendlesohn, "Introduction," in The Cambridge Companion to Science Fiction, eds. Edward James and Farah Mendlesohn (Cambridge: Cambridge University Press, 2003), 1-15. Even if these two categories have been used interchangeably, I believe we should distinguish between them. Here I want to suggest that the sublime summons a sensory experience that may lead to a sense of inadequacy, whereas the sense of wonder recalls a cognitive response that invites a sense of possibility. This is why it may be associated with the visions of the genius.

29. "Capturing a sense of power and wonder, Robbins's promotional materials are replete with images of nature as a force to be reckoned with: volcanoes, tidal waves, lightning strikes, and other images of natural power that suggest potency and flows. Indeed, Robbins, like the mind-power advocates of the early twentieth century, assures readers that everyone can tap into a universal consciousness or flow." See McGee, 63.

30. Bowdon, 50 Self-Help Classics, 1.

31. For instance, the self that takes control over its life in spite of genetic markers or predispositions, like a "warrior gene."

32. Drew Berry (2011), "Animations of Unseeable Biology." Filmed May 2011 in Sydney, Australia. TEDx video, 01:08-01:50, https://www.ted.com/talks/drew_berry_ animations_of_unseeable_biology.
33. James Watson (2005), "How We Discovered DNA." Filmed February 2005 in Oxford, UK. TED video, https://www.ted.com/talks/james_watson_how_we_discovered_dna.

34. Jennifer Doudna, "How CRISPR Lets Us Edit Our DNA." Filmed September 2015 in London, UK. TED video, 05:43, https://www.ted.com/talks/jennifer_doudna_how_ crispr_lets_us_edit_our_dna. Spencer Wells (2007), "A family Tree For Humanity." Filmed June 2007 in Arusha, Tanzania. TED video, 08:05, https://www.ted.com/talks/ spencer_wells_a_family_tree_for_humanity.

35. Barry Schuler (2008), "Genomics 101." Filmed July 2008 in Napa, USA, at Taste3. TED video, 11:51, https://www.ted.com/talks/barry_schuler_genomics_101.

36. The act of building a human being has also been reimagined as $3 \mathrm{D}$ printing in the American science fiction television series Westworld, which was broadcasted in 2016, the same year in which Sabatini gave his talk.

37. It is worth mentioning that in the meantime, the company's value has declined and its employee count has dropped. Company co-founder Venter has also stepped down from the company. See Kenvin Truong (2018), "Former unicorn genetics startup Human Longevity loses its horn," MedCityNews, December 10, 2018, https://medcitynews. com/2018/12/former-unicorn-genetics-startup-human-longevity-loses-its-horn/. Peter Diamandis has also cofounded the so-called Singularity University with transhumanist Ray Kurzweil. The organisation offers courses taught by transhumanists and it is an affiliate of Humanity+. See Roberto Manzocco (2019b), Transhumanism - Engineering the Human Condition: History, Philosophy and Current Status (Dordrecht: Springer, 2019), 51. See https://humanityplus.org/about/affiliates/.

38. Riccardo Sabatini (2016), "How to Read the Genome and Build a Human Being." Filmed February 2016 in Vancouver, Canada. TED video, 14:40, https://www.ted.com/ talks/riccardo_sabatini_how_to_read_the_genome_and_build_a_human_being.

39. Schuler, "Genomics 101," 18:12.

40. Schuler, "Genomics 101," 18:56.

41. Schuler, "Genomics 101," 20:45.

42. See Lily Kay (2000), Who Wrote the Book of Life?: A History of the Genetic Code (Stanford: Stanford University Press).

43. Sabatini uses a physical vial of blood as a prop to emphasise its potential to carry information. His gesture echoes the practice of translating blood into code, which has previously occurred with the introduction of blood types.

44. Watson, "How We Discovered DNA," 02:20.

45. Watson, "How We Discovered DNA," 10:54, 12:36.

46. Schuler, "Genomics 101," 03:55.

47. Juan Enriquez (2015), "We Can Reprogram Life. How to Do It Wisely." Filmed November 2015 in New York, USA. TED video, https://www.ted.com/talks/juan_ enriquez_we_can_repr ogram_life_how_to_do_it_wisely.

48. Wells, "A Family Tree for Humanity," 07:50.

49. Sabatini, "How to Read the Genome and Build a Human Being," 04:07.

50. Sabatini, "How to Read the Genome and Build a Human Being," 03:12.

51. Sabatini, "How to Read the Genome and Build a Human Being," 06:03.

52. This transcendent dimension has already been implied in the belief that DNA is the "essence" of life. However, the emphasis on the miraculous aspect of it makes it even more explicit.

53. Sabatini, "How to Read the Genome and Build a Human Being," 05:02.

54. Sabatini, "How to Read the Genome and Build a Human Being," 05:39.

55. See Evelyn F Keller (2002), Making Sense of Life: Explaining Biological Development with Models, Metaphors, and Machines (Cambridge, Mass: Harvard University Press), and Judith Roof (2007), The Poetics of DNA (Minneapolis: University of Minnesota Press).

56. D Nelkin (2001), "Molecular Metaphors: The Gene in Popular Discourse." Nature Reviews Genetics 2, 555-59 (p. 557). https://doi.org/10.1038/35080583.

57. Nelkin, "Molecular Metaphors: The Gene in Popular Discourse," 556.

58. Sabatini, "How to Read the Genome and Build a Human Being," 14:14.

59. Keolu Fox (2016), "Why Genetic Research Must Be More Diverse." Filmed February 2016 in Vancouver, Canada. TED video, 04:30, https://www.ted.com/talks/keolu_fox_ why_geneti c_research_must_be_more_diverse.

60. Fox, "Why Genetic Research Must Be More Diverse," 01:15

61. Fox, "Why Genetic Research Must Be More Diverse," 05:30.

62. Recently, the figure of the citizen scientist has been appropriated by proponents of human enhancement to promote individual acts of discovery, including DIY or biohacking practices. In an interview with $H+$, Joseph Jackson cites Thomas Jefferson and Benjamin Franklin as representatives of citizen science and he reinforces the notion of the individual genius as a common man. So, the citizen scientist "uses the scientific method to investigate themselves or their environment." See Alex Lightman (2013), "The Rise of the Citizen Scientist," Best of H+ Magazine, Volume 1 (2008-2010). Eds. R.U. Sirius, Ben Goertzel and David Orban: 13-21. https://goertzel. org/BestOfH+MagazineVolume1.pdf. By contrast, the kind of citizen science defined in the project by Sally Shuttleworth and Sally Frampton (2015) values public participation 
over individual projects and challenges the notion of individual genius. See Sally Shuttleworth and Sally Frampton, "Constructing Scientific Communities: Citizen Science," Perspectives, 385 (June 27, 2015), 2568. DOI: https://doi.org/10.1016/ S0140-6736(15)61150-3.

63. Stephen Friend (2014), "The Hunt for 'Unexpected Genetic Heroes.'” Filmed March 2014 in Vancouver, Canada. TED video, 10:07, https://www.ted.com/talks/stephen_ friend_the_h unt_for_unexpected_genetic_heroes.

64. Resnick, "Welcome to the Genomic Revolution," 10:35.

65. McGee offers at least two examples of how mortality is treated in self-help: he discusses the accident-victims-turned-heroic-survivors paradigm (150-51) and Deepak Chopra's promise of a "version of immortality through mind-body medicine" (71) Anne Harrington (2008) has also tackled the intricate connections between mind-body medicine and self-help culture in America: from 1965 century New Thought books to Peale's notion of mental healing. Barbara Ehrenreich offers a critique of the survivor paradigm and the idea of mental healing in her work, too. See Barbara Ehrenreich (2009), Bright-Sided: How Positive Thinking Is Undermining America (New York: Picador).

66. Bowdon, 50 Self-Help Classics, 8.

67. See https://humanityplus.org/.

68. This is how Juan Enriquez is introduced as a speaker on the TED website: https://www. ted.com/speakers/juan_enriquez.

69. Juan Enriquez (2016), "What Will Humans Look Like in 100 Years?" Filmed June 2016 in Banff, Canada. TED video, 00:16, https://www.ted.com/talks/juan_enriquez_what_ will_hum ans_look_like_in_100_years.

70. Enriquez, "What Will Humans Look Like in 100 Years," 00:42-01:47. Hugh Herr (2014) Hugh Herr is a bionics designer at the Center for Extreme Bionics at the MIT Media Lab who lost both of his legs and wears bionic limbs himself. He has also introduced his work in a viral TED talk that is also listed in the playlist " 11 must-see TED Talks": "The new bionics that let us run, climb and dance" (2014). In 2018, he gave another talk on "How we'll become cyborgs and extend human potential", which celebrates the prospect of human enhancement.

71. Enriquez, "What Will Humans Look Like in 100 Years," 01:47-02:04.

72. Enriquez, "What Will Humans Look Like in 100 Years," 03:04.

73. Enriquez, "What Will Humans Look Like in 100 Years," 03:08, 03:30.

74. Enriquez, "What Will Humans Look Like in 100 Years," 04:33.

75. Enriquez, "The Age of Genetic Wonder," 09:17-09:47.

76. McGee, Self-Help, Inc., 51.

77. McGee, Self-Help, Inc., 60.

78. Enriquez, "What Will Humans Look Like in 100 Years," 14:10-15:37.

\section{BIBLIOGRAPHY}

Anderson, Tony. "Benjamin Franklin: The Unlikely Father of Self-Help." Blinkist Magazine, 2018. https://www.blinkist.com/magazine/posts/benjamin-franklinfather-self-help.

Berry, Drew. "Animations of Unseeable Biology." Filmed May 2011 at TEDxSyndey, Sydney, Australia. Video, 09:08, 2011. https://www.ted.com/talks/drew_berry_animations_ of_unseeable_biology.

Butler-Bowdon, Tom. 50 Self-Help Classics: 50 Inspirational Books to Transform Your Life. London, Yarmouth, Maine: Nicholas Brealey Pub, 2003.

De Certeau, Michel. The Practice of Everyday Life. Berkeley, Los Angeles, London: University of California Press, 1984.

Doudna, Jennifer. "How CRISPR Lets Us Edit Our DNA." Filmed September 2015 at TEDGlobal>London, London, UK. Video, 15:53, 2015. https://www.ted.com/talks/ jennifer_doudna_how_crispr_lets_us_edit_our_dna.

Ehrenreich, Barbara. Bright-Sided: How Positive Thinking Is Undermining America. New York: Picador, 2009

Enriquez, Juan. "We Can Reprogram Life. How to Do It Wisely." Filmed November 2015 at TED Talks Live, New York, USA. Video, 14:49, 2015. https://www.ted.com/talks/juan_ enriquez_we_can_reprogram_life_how_to_do_it_wisely.

. "What Will Humans Look Like in 100 Years?" Filmed June 2016 at TEDSummit, Banff, Canada. Video, 15:45, 2016. https://www.ted.com/talks/juan_ enriquez_what_will_humans_look_like_in_100_years.

. "The Age of Genetic Wonder." Filmed November 2018 at TEDxCERN, Geneva, Switzerland. Video, 18:05, 2018. https://www.ted.com/talks/juan_enriquez_ the_age_of_genetic_wonder_feb_2019.
Fox, Keolu. "Why Genetic Research Must Be More Diverse." Filmed February 2016 at TED, Vancouver, Canada. Video, 06:48, 2016. https://www.ted.com/talks/keolu_fox_why_ genetic_research_must_be_more_diverse.

Friend, Stephen. "The Hunt for 'Unexpected Genetic Heroes." Filmed March 2014 at TED, Vancouver, Canada. Video, 10:39, 2014. https://www.ted.com/talks/stephen_friend_ the hunt for unexpected genetic heroes.

Fukuyama, Francis. Our Posthuman Future: Consequences of the Biotechnological Revolution. New York: Farrar Straus and Giroux, 2002

Harrington, Anne. The Cure Within: A History of Mind-Body Medicine. New York: W.W. Norton \& Company, 2008.

Herr, Hugh. "The New Bionics That Let Us Run, Climb and Dance." Filmed March 2014 at TED, Vancouver, Canada. Video, 19:00, 2014. https://www.ted.com/talks/hugh_herr_ the_new_bionics_that_let_us_run_climb_and_dance.

Hicklin, Tianna. "The Start of a New Genomic Era." CRISPR-CAS: Engineering a Revolution in Gene Editing, Science, 2014. https://www.sciencemag.org/sites/default/files/ custom-publishing/documents/CRISPR-Cas9_booklet_LowRes.pdf.

Kahn, Jennifer. "Gene Editing Can Now Change an Entire Species — Forever." Filmed February 2016 at TED, Vancouver, Canada. Video, 12:25, 2016. https://www.ted.com/ talks/jennifer_kahn_gene_editing_can_now_change_an_entire_species_forever.

Kay, Lily. Who Wrote the Book of Life?: A History of the Genetic Code. Stanford: Stanford University Press, 2000.

Keller, Evelyn F. Making Sense of Life: Explaining Biological Development with Models, Metaphors, and Machines. Cambridge, Mass: Harvard University Press, 2002.

Knoepfler, Paul. "The Ethical Dilemma of Designer Babies." Filmed October 2015 at TEDxVienna, Vienna Austria. Video, 18:19, 2015. https://www.ted.com/talks/paul_ knoepfler_the_ethical_dilemma_of_designer_babies\#t-8728.

Liang, Puping, Yanwen Xu, Xiya Zhang, Chenhui Ding, Rui Huang, Zhen Zhang, Jie Lv., et al. "Crispr/Cas9-Mediated gene editing in human tripronuclear zygotes." Protein \& Cell 6, no. 5 (2015): 363-72.

Lightman, Alex. "The Rise of the Citizen Scientist." In Best of H+ Magazine, vol. 1, edited by R. U Sirius, Ben Goertzel, and David Orban, 13-21, 2013. https://goertzel.org/ BestOfH+MagazineVolume1.pdf

Ludewig, Julia. " "TED talks as an emergent genre." CLCWeb: Comparative Literature and Culture 19, no. 1 (2017)

Manzocco, Roberto. Transhumanism - Engineering the Human Condition: History, Philosophy and Current Status. Dordrecht: Springer, 2019b.

McGee, Micki. Self-Help, Inc.: Makeover Culture in American Life. Oxford: Oxford University Press, 2005.

Mendlesohn, Farah. "Introduction." In The Cambridge Companion to Science Fiction, edited by James Edward, and Mendlesohn Farah, 1-15. Cambridge: Cambridge University Press, 2003.

Nelkin, D. "Molecular metaphors: the gene in popular discourse." Nature Reviews Genetics 2, no. 7 (2001): 555-9.

Resnick, Richard. "Welcome to the Genomic Revolution." Filmed July 2011 at TEDxBoston, Boston, USA. Video, 11:02, 2011. https://www.ted.com/talks/richard_resnick_ welcome to the genomic revolution.

Robu, Cornel. "A key to science fiction: the Sublime." Foundation 42 (1988): 21-37.

Roof, Judith. The Poetics of DNA. Minneapolis: University of Minnesota Press, 2007.

Sabatini, Riccardo. "How to Read the Genome and Build a Human Being." Filmed February 2016 at TED, Vancouver, Canada. Video, 15:28, 2016. https://www.ted.com/talks/ riccardo_sabatini_how_to_read_the_genome_and_build_a_human_being.

Sandel, Michael J. The Case Against Perfection: Ethics in the Age of Genetic Engineering. Cambridge: Belknap Press of Harvard University Press, 2007.

Sawyer, Andy. "Science Fiction: The Sense of Wonder." In The Bloomsbury Introduction to Popular Fiction, edited by Christine Berberich, 87-107. London: Bloomsbury Publishing, 2014.

Schuler, Barry. "Genomics 101." Filmed July 2008 at Taste3, Napa, USA. TED Video, 21:26, 2008. https://www.ted.com/talks/barry_schuler_genomics_101.

Shuttleworth, Sally, and Sally Frampton. "Constructing scientific communities: citizen science." The Lancet 385, no. 9987 (2015), 2568.

Sugimoto, Cassidy R, Mike Thelwall, Vincent Larivière, Andrew Tsou, Philippe Mongeon, Benoit Macaluso, Thelwall Mike. "Scientists popularizing science: characteristics and impact of TED talk presenters." PLOS ONE 8, no. 4 (2013), e62403.

Truong, Kenvin. "Former Unicorn Genetics Startup Human Longevity Loses Its Horn." MedCityNews, 2018. https://medcitynews.com/2018/12/former-unicorn-geneticsstartup-human-longevity-loses-its-horn/.

Watson, James. "How We Discovered DNA." Filmed February 2005 at TED, Oxford, UK. Video, 20:11, 2005. https://www.ted.com/talks/james watson how we discovered dna.

Wells, Spencer. "A Family Tree for Humanity." Filmed June 2007 at TEDGlobal, Arusha, Tanzania.Video, 20:53, 2007. https://www.ted.com/talks/spencer_wells_a_family_ tree_for_humanity. 